\section{PP-113 陰茎癌症例の臨床的检討}

\begin{abstract}
横浜市立大学附属市民総合医療センター泌尿器科・腎移植 科 ${ }^{2}$ ，横浜市立横浜市民病院泌尿器科 ${ }^{2}$, 神奈川県立がん センター泌尿器科 ${ }^{3)}$, 横浜市立大学附属市民総合医療セン ター病理部4)
\end{abstract}

湯村 寧1), 平澤 輝一"), 小林 将貴 ${ }^{1)}$, 古屋 一裕 ${ }^{1)}$, 春日 紲 ${ }^{1}$, 中村 昌史 ${ }^{1}$, 寺西 淳一 ${ }^{12}$, 三好 康秀 ${ }^{1)}$,

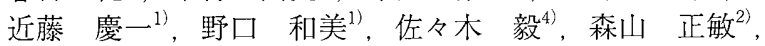
三浦 猛3

【はじめに】陰茎癌は泌尿器科悪性腫瘍のなかではまれな疾患 であり、その病態や予後についても不明な点が多い。今回我々 は陰茎癌症例 78 例の病理所見・治療法・予後について検討を 行った。結果に若干の考察を加元報告する。【対象および方 法】1988 年 4 月から 2008 年 11 月の間に横浜市立大学泌尿器 科の関連 23 施設において経験された陰荃癌症例 78 例を対象 とした。初診時の平均年齢は 67.0 歳（46～91 歳）であった。 78 例の病理結果、治療法、生存率を調査し、予後因子を単変 量並びに多変量解析を用いて検討した。【結果】追跡期間の中 央值は 40.6 ヶ月 $(3.0 \sim 248.1$ ケ月) であり、うち 68 例が陰 茥切除を行っていたが鼠経部のリンパ節郭清を行ったのは 30 例であった。抗癌剂治療は 33 例に行われておりその多くは BLMを中心としたものであった。 1 症例が 45 例と最も多く、 $\mathrm{T} 2$ 以上の進行癌は 33 例であった。追跡期間中に 20 例が澏死 し、 78 例の 5 年生存率は $65.9 \% 、 10$ 年生存率は $61.5 \%$ であっ た。予後規定因子として、単変量解析では浸潤様式、脈管、 リンパ管浸潤の有無、リンパ節転移の有無、他臟器転移の有無、 残存腫演の有無が举げられ、多変量解析では脈管浸潤の有無 と残存腫場の有無が予後因子と考光られた。

\section{PP-114 陰茎癌の臨床的検討}

\section{国立病院機構仙台医療センター泌尿器科1，国立病院機構 西多賀病院泌尿器科 ${ }^{2)}$}

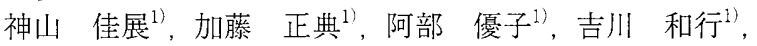
武弓 倰一 ${ }^{23}$

【目的】陰茥癌は比較的稀な疾患であり、治療法も確立さ れたものが無いというのが現状である。今回我々は、㓌茥 癌症例の臨床的検討を行ったので報告する。【対象】1995 年 3 月から 2009 年 4 月までに当科で診療を行った 15 例を 対象とした。【結果】年齢は平均 67 歳（40 歳から 89 歳） であった。真性包茎の合併は 15 例中 11 例に認めた。臨床 病期は stagel が 6 例、 stage 2 が 4 例、 stage 3 が 5 例であ り、遠隔転移を恋めた症例はいなかった。治療は、腫瘤摘 出術が 2 例、㓌茎部分切除術が 11 例、㓌茎全摘除術が 2 例であった。全例が sentinel lymph node biopsyを施行し、 内 5 例がリンパ節陽性であった。原発巣の病理結果は、全 例 SCC であった。また、術前後の化学療法施行が 4 例、 放射線照射は 4 例であった。15例中 stage 3 の 3 例が再発 し、内 2 例が癌死したが、1 例は化学療法、放射線療法の 集学的治療で寞解し、治療開始後 9 年で他因死した。【結 論】陰茎癌症例では、初めの staging が重要であり、high stage でも早期の適切な治療で根治が期待できる症例があ る。

\section{PP-115 陰茎癌の臨床的検討} 高山赤十字病院泌尿器科 ${ }^{1)}$, 岐阜陰茥癌研究グループ2),
岐阜大学医学部大学院医学系研究科泌尿器科学

加藤 卓 ${ }^{1\rangle}$, 豊田 将平 ${ }^{2}$, 高木 公暁 ${ }^{2}$, 堀江 憲吾 ${ }^{2}$, 永井 真吾 ${ }^{2}$, 服部 慎一 ${ }^{22}$, 中根 慶太 ${ }^{22}$, 清家 健作 ${ }^{22}$, 後藤高広 ${ }^{2}$, 増栄 成泰 ${ }^{2}$, 王木 正義 ${ }^{2}$, 伊藤 康久 ${ }^{2}$, 出口 隆3

【目的】陰茎癌は稀な疾患であり、まとまった報告は少な い。今回我々は岐皁大学㧍よび関連施設での陰茎癌症例に 関する検討を行った。【対象】岐皁大学および関連 8 施設 において 1997 年 1 月から 2009 年 6 月の間に陰茎癌と診 断された 24 例を対象とした。【結果】年齢は平均 70.7 歳 (46〜 88)、平均観察期間は 18.5 ケ月（1.3～95.9）。主訴 は陰茎腫瘤が 8 例、陰荎痛が 4 例、その他 12 例であり包 菱は 21 例 $(87.5 \%)$ に認めた。鼠径リンパ節腫脹は 13 例 （54.2\%）に認めた。診断時 SCC 抗原は平均 4.15ng/ml (1.2 〜 14.1) であった。手術は陰茥全摘除が 7 例、陰茎部分切 除 12 例、環状切除 4 例、膀脱全摘除術および全除精術 1 例、 未施行 1 例で鼠径リンパ節郭清術は5例に施行されていた。 摘出標本の病理学的診断は高分化型扁平上皮癌 10 例、中 分化型 2 例、低分化型 2 例、不明 10 例であり T1、7 例、 $\mathrm{T} 2 、 6$ 例、T3、5 例、T4、2 例、TX、3 例、化学療法が 施行された症例は 5 例あり術前化学療法を施行した 1 例の 摘出標本がT0であった。リンパ節転移は 10 例に認めた。 経過中 9 例が癌死しており、T2 以上の症例、リンパ節転 移を認める症例は有意に癌死が多かった。( $\mathrm{p}<0.05)$ 今 後さらに症例数を増やし検討する予定である。

\section{PP-116当院における陰茎異物の臨床的検討}

鹿児島大学大学院医歯学総合研究科泌尿器科学 ${ }^{11}$, 鹿児島 大学大学院医歯学総合研究科皮膚科学 ${ }^{2}$, 今給黎総合病院 泌尿器科 ${ }^{3)}$

内田 洋介 ${ }^{1)}$, 伏谷 倰作 ${ }^{1 j}$, 杉田 智 ${ }^{1)}$, 鶴田 雅史 ${ }^{1.2}$, 松下 茂人 ${ }^{2)}$, 米倉 健太郎 ${ }^{2)}$, 種田 洋史 ${ }^{3)}$,

中目 康彦3', 西山賢龍 ${ }^{3}$, 中川 昌之 ${ }^{1)}$

陰茎異物はまれな疾患ではあるが、それ故に対処に苦慮す る場合も多い。我々は 1998 年 10 月から 2009 年 9 月まで の 11 年間に 5 例の陰茎異物注入症を経験したので報告す る。年齢は 35 歳から 56 歳までで中央值は 44 歳であった。 異物はワセリンが 4 名、スタンプ用インクが1名であった。 受診時期は注入後 1 週間から 16 年であった。主訴は性交 不能、性交時痛などであった。ワセリンの症例は異物摘出 を行い、1 例は大腿部からの植皮を行った。スタンプ用イ ンクの症例は壊死した皮膚を環状切除の要領で除去し、 残った皮膚を縫合した。術後経過はいずれも順調であった。 